Cinémas

Revue d'études cinématographiques

Journal of Film Studies

\title{
Ouvrages reçus / Books Received
}

Volume 5, numéro 3, printemps 1995

URI : https://id.erudit.org/iderudit/1001156ar

DOI : https://doi.org/10.7202/1001156ar

Aller au sommaire du numéro

Éditeur(s)

Cinémas

ISSN

1181-6945 (imprimé)

1705-6500 (numérique)

Découvrir la revue

Citer ce document

(1995). Ouvrages reçus / Books Received. Cinémas, 5(3), 195-195.

https://doi.org/10.7202/1001156ar d'utilisation que vous pouvez consulter en ligne.

https://apropos.erudit.org/fr/usagers/politique-dutilisation/ 


\section{Ouvrages reçus / Books Received}

ALLEN, Robert C. et GOMERY, Douglas. Faire l'histoire du cinéma. Les modèles américains. Paris: Nathan, 1993, 319 p.

BÉRUBÉ, Bernard et MAGNAN, Richard. Les Films québécois aux États-Unis (1980-1991). Montréal: Centre de recherche cinéma/ réception de l'Université de Montréal et Cinémathèque québécoise / Musée du cinéma, 1994, 109 p.

DANEY, Serge. Persévérance. Paris: P.O.L. Éditeur, 1994, 172 p.

FARIS, Jocelyn. Jayne Mansfield. A Bio-Bibliography. Westport / London: Greenwood Press, 1994, 284 p.

GILI, Jean A. Paolo et Vittorio Taviani: Entretien au pluriel. Arles: Institut Lumière / Actes Sud, 1993, 219 p.

MAINDRON, André (direction). Littérature de langue française en Amérique du Nord. La Licorne, n 27, 1993, 448 p.

OSTERHOLM, J. Roger. Bing Crosby. A Bio-Bibliography. Westport / London: Greenwood Press, 1994, 474 p.

PRÉDAL, René (direction). Le Néoréalisme italien. Paris : Corlet-Télérama (CinémAction, $\mathrm{n}^{\circ} 70$ ), $235 \mathrm{p}$.

RHEINGOLD, Howard. La Réalité virtuelle. Paris: Dunod, $1994,414 \mathrm{p}$.

TASKER, Yvonne. Spectacular Bodies: Gender, Genre and the Action Cinema. London: Routledge, 1993, 195 p. 